\title{
Effect of maturity on the phytonutrient composition of Cape gooseberry seeds (Physalis peruviana L.)
}

\author{
Venelina Popova ${ }^{1, *}$, Tanya Ivanova $^{1}$, Zhana Petkova $^{2}$, Magdalena Stoyanova $^{3}$, Albena Stoyanova $^{1}$, Nadezhda \\ Mazova $^{3}$ and Nikolay Panayotov ${ }^{4}$ \\ ${ }^{1}$ Department of Tobacco, Sugar, Vegetable and Essential Oils, University of Food Technologies, Plovdiv, Bulgaria \\ ${ }^{2}$ Department of Chemical Technology, Plovdiv University "Paisii Hilendarski”, Plovdiv, Bulgaria \\ ${ }^{3}$ Department of Analytical Chemistry and Physical Chemistry, University of Food Technologies, Plovdiv, Bulgaria \\ ${ }^{4}$ Department of Horticulture, Agricultural University, Plovdiv, Bulgaria
}

\begin{abstract}
The seeds of Cape gooseberry (Physalis peruviana L.) remain as a by-product from juice production, but they can also be a potential resource of valuable nutrients. The objective of this study was to analyze the phytonutrient composition of the seeds isolated from fruit at two maturity stages unsuitable for regular realization (unripe and under-ripe), with the aim of identifying the possibility for utilization of such non-standard or discarded agricultural production. The results showed about 3-time lower oil content in the unripe seeds than in the under-ripe seeds $(6.60 \%$ vs. $21.75 \%)$, but no significant differences in the content of protein (18.44\% and $17.83 \%)$ and cellulose (26.63\% and $26.14 \%)$. The total tocopherol content slightly decreased with the progress of fruit maturity (from $8354 \mathrm{mg} / \mathrm{kg}$ to $7118 \mathrm{mg} / \mathrm{kg}$ ). Significant changes in the amino acid composition were found only with regard to aspartic acid, glutamic acid, tyrosine and methionine. The content of macro and micro minerals was lower in the under-ripe seeds (about 1.5-2-time). The results from this baseline study suggested that the seeds from both unripe and under-ripe fruit could also be considered for nutritive purposes (animal feed, food products).
\end{abstract}

\section{Introduction}

Physalis, a genus of herbaceous plants in the family Solanaceae, comprises over 100 species, among which Cape gooseberry (Physalis peruviana L.) is one of the prevalent and commercially important [1]. The species originates from the Andean region and nowadays is cultivated worldwide, in Central and South Europe, the Americas, Asia, the Pacific, and other regions [2]. Traditionally, Colombia has been the largest supplier of Cape gooseberry fruit, with annual production of about 11500 tones and annual export of about 6000 tones [3, 4].

The fruit of the plant are small (diameter up to $3 \mathrm{~cm}$, weight about 4-10 g), ovate, bright yellow to orange berries, embraced by a papery husk (calyx), which contain between 100 and 300 seeds [2]. The seeds are creamy white to yellowish, flat, very small, with diameter less than $2 \mathrm{~mm}$ and weight less than $1 \mathrm{mg}$, but they constitute about $7-13 \%$ of fruit weight [5-7]. Many studies have identified Cape gooseberry fruit as a rich source of phytonutrients, important in human diet, such as vitamins $[4,8]$, minerals $[9,10]$, carotenoids [11], carbohydrates $(2,10]$, fatty acids, and others [11-13]. Relatively limited research, however, has focused on the properties of Cape gooseberry fruit by-products, considered as waste in the industrial process (calyx, seeds, seed/peel pomace), despite their significant amounts and the recognition of their important role in folk medicine, associated with anti- inflammatory, anti-proliferative, antiseptic, and other pharmacological effects [14]. Cape gooseberry seeds have been identified as sources of protein, essential amino acids, dietetic fibers, minerals, phenolics, and other nutrients $[5,6,12,15]$. Seeds concentrate about $90 \%$ of the total oil content in the fruit $[2,11]$; due to the high concentration of tocopherols, sterols, vitamins, and other bioactive compounds, seed oil has been assessed as a product of high nutritional value, which could find wider use in functional and dietetic food industry, as well as in phytopharmacy $[2,11,12,14,16]$. The light yellow color of the oil extracted from Cape gooseberry seeds and seed/peel pomace make it suitable as a natural colorant, improving the visual perception of foods $[12,17]$. Juice extraction in fruit processing produces serious amounts of pomace (waste, comprised of seeds, peels and pulp/juice residues), as it constitutes about $27.4 \%$ of fruit weight [12]; the seed/peel pomace has been characterized as a potentially valuable source of phytonutrients in food production [6, 12, 17]. It has been suggested that, in certain respects, the phytonutrient potential of seeds and seed/peel pomace from different juicy fruits, like papaya or passion fruit, may exceed that of fruit pulp [15, 18, 19].

Cape gooseberry is still a rare vegetable crop in Bulgaria, although species potential has been appreciated more than 20 years ago and a local variety named "Plovdiv" has been selected and officially recognized as original by the national authorities [20]. According to the

* Corresponding author: vpopova2000@abv.bg 
recommended production scheme adapted to the ecological conditions of the country plant transplanting begins around the middle of May and fruit harvesting starts from the middle of August. The plants of the variety reach an average height of $160-170 \mathrm{~cm}$, producing about $130 \mathrm{~g}$ fruit per plant, thus securing yield up to $380 \mathrm{~kg} / \mathrm{d}$ $[20,21]$. Recently, Cape gooseberry has shown potential for growing on metal-contaminated soils in the country, as well [22].

Cape gooseberry plants have a long vegetation period, and fruit harvesting is performed regularly during the season; the frequency of harvests depends on the stage of the plant and the production level $[3,23]$. Therefore, fruit maturity at harvest is a key factor in Cape gooseberry production and quality, as it strongly influences fruit nutritional value and post-harvest behavior. Many studies have focused on the determination of the optimal maturity stage of Cape gooseberry fruit, depending on their intended realization, as well as on the influence of ripening on fruit physical properties and chemical composition [9, 24-29]. The requirements for Cape gooseberry fruit quality, both for consumer supply or industrial processing, are set by established regulations $[30,31]$. The standards specify criteria - based on fruit characteristics such as size, calyx and berry color, injuries, firmness, total soluble solids, acidity, etc. - for fruit classification in different groups (categories) and the respective acceptable tolerances. It is known that not fully ripe but physically developed fruit (horticulture maturity) have good potential for post-harvest ripening (for 2-3 weeks) and realization, as Cape gooseberry fruit, like other small fruit species, is climacteric [3,32]. Thus, it has been recommended to harvest fruit at stage 4 (semi-ripe) [31] for post-harvest storage and at stages 5 and 6 (fully ripe) [31] - for immediate consumption [13, 27]. At the end of the growing season, however, before the autumn frosts, a considerable proportion of fruit fails to achieve the appropriate development and ripeness of regular produce; such unripe fruit are left on the field and later discarded as agricultural waste, together with the stems and leaves. In Bulgaria, the share of green fruit by the end of the season has been found to be between $8.7 \%$ and $17.3 \%$, but even bigger percentage is possible if higher fertilization rates or other stimulating agro-practices are applied [33]. There have been very limited investigations on the properties of Cape gooseberry fruit at the early maturity stages, which are unsuitable for post-harvest ripening, and respectively - for conventional market or industrial processing realization. Such fruit, however, could be considered in agricultural waste recovery, as it has been suggested for the rest of the waste biomass in Cape gooseberry production (stems, leaves, calyces) [14, $34,35]$.

To the best of our knowledge, there have been no previous studies on the chemical composition of the seeds from unripe and under-ripe fruit, as well as such considering their use potential. We hypothesized that the regarded waste material could reveal certain nutritional value, as well as that fruit ripeness stage would be a factor in seed composition differentiating between their individual components. Therefore, the objectives of this study were to analyze the phytonutrient composition of the seeds isolated from fruit at two maturity stages, unsuitable for regular realization (unripe and under-ripe), with the view of identifying possibilities for value-added use of this non-standard, currently discarded agricultural production. The outcomes from the study could provide new data on Cape gooseberry by-product potential in nutrition and waste recovery, as well as such about Cape gooseberry specifics in Bulgaria.

\section{Materials and methods}

\subsection{Plant material}

The initial plant materials in the study were Cape gooseberry fruit at two early ripeness stages (unripe and under-ripe), harvested from the plants of the only original Bulgarian variety of the species, variety "Plovdiv" [20]. The plants were cultivated in 2018 on the experimental fields of the Agricultural University, Plovdiv. Fruit were collected by hand at the end of the season, after the last regular harvest, and then were divided by ripeness categories. Fruit development stage was assessed in terms of berry color, according to Icontec NTC 4580 regulation [31]. Unripe fruit samples in the study (not fully developed, green) corresponded to groups 0 and 1 , and the under-ripe fruit category (light orange with green zones) - to groups 2 and $3[27,31]$.

Fruit were kept for up to 3-5 days in a refrigerator, at $5-8^{\circ} \mathrm{C}$, to avoid biochemical transformations, and then the seeds were carefully isolated by hand. Seeds were rinsed thoroughly with distilled water to remove all juice, pulp and peel residues, and then were air-dried.

Seed moisture content was determined by oven-drying to constant weight at $103 \pm 2{ }^{\circ} \mathrm{C}$. All results in the study are given on a dry weight basis (DW).

\subsection{Chemical analyses}

\subsubsection{Fatty acid and tocopherol composition of Cape gooseberry seed oil}

The glyceride oil $(\%, w / w)$ was isolated from the seeds by Soxhlet extraction with n-hexane for $8 \mathrm{~h}$, after which the solvent was removed on a rotary vacuum evaporator operated at water bath temperature $40^{\circ} \mathrm{C}$ [36].

The fatty acid composition of the oil was determined according to the standard methods $[37,38]$. Lipid transmethylation was achieved at $50^{\circ} \mathrm{C}$, with $2 \% \mathrm{H}_{2} \mathrm{SO}_{4}$ in $\mathrm{CH}_{3} \mathrm{OH}$. The $\mathrm{GC}$ analysis was carried out on a Hewlett Packard 5890 A unit equipped with a Supelco 2560 capillary column $(75 \mathrm{~m} \times 0.25 \mathrm{~mm} \times 18 \mu \mathrm{m})$ and a flame ionization detector (FID). The chromatographic conditions were: column temperature $130^{\circ} \mathrm{C}(4 \mathrm{~min})$, $15^{\circ} \mathrm{C} / \mathrm{min}$ to $240^{\circ} \mathrm{C}(5 \mathrm{~min})$; injector and detector temperatures $250^{\circ} \mathrm{C}$; hydrogen at $0.8 \mathrm{~cm}^{3} / \mathrm{min}$ constant rate; split 50:1. Fatty acid (FA) identification was through comparison of the retention times with those of a standard mix of FA methyl esters.

Tocopherols were determined by HPLC directly in the oil, on a Merck-Hitachi unit, coupled to a Nucleosil Si 50- 
5 column $(250 \mathrm{~mm} \times 4 \mathrm{~mm})$ and a fluorescent detector Merck-Hitachi F 1000. The analytical conditions were: nhexane: dioxane (96:4) mobile phase; $1.0 \mathrm{~cm}^{3} / \mathrm{min}$ flow rate; excitation at $290 \mathrm{~nm}$, emission at $330 \mathrm{~nm}$; injection volume $20 \mu \mathrm{l}$. Tocopherol identification was according to [39], using tocopherol standards; DL- $\alpha-$, DL- $\beta-$, DL- $\gamma-$ and DL- $\delta$-tocopherols, 98\% purity (Merck, Darmstadt, Germany).

\subsubsection{Mineral composition of Cape gooseberry seeds}

The contents of individual minerals in the seed samples were determined by atomic absorption spectrometry (AAS) [40], on a Perkin Elmer/HGA 500 spectrometer (Norwalk, USA). The parameters of the AAS analysis and the identification of the elemental composition were as previously described [6].

\subsubsection{Protein, amino acids and cellulose in Cape gooseberry seeds}

Protein content in Cape gooseberry seeds was determined according to AOAC Method 976.06 [41], using an UDK 152 Kjeldahl system (Velp Scientifica, Italy).

Amino acid identification was carried out using the AccQ-Fluor kit (WATO52880, Waters Corporation, USA) for the derivatization of hydrolyzed amino acids and an HPLC unit comprised of ELITE LaChrome (Hitachi) instrument, diode-array detector (DAD) and C18 AccQ-Tag column $(3.9 \mathrm{~mm} \times 150 \mathrm{~mm})$. The injected volume was $20 \mu \mathrm{l}$; the mobile phases comprised of WATO52890 buffer and $60 \%$ acetonitrile; absorbance was read at $254 \mathrm{~nm}$ and column temperature $37^{\circ} \mathrm{C}$.

Cellulose content in the seeds was determined according to the method by [42], including cellulose and hemicellulose hydrolysis ( $1 \mathrm{~g}$ sample in $16.5 \mathrm{~cm}^{3} 80 \%$ $\mathrm{CH}_{3} \mathrm{COOH}$ and $1.5 \mathrm{~cm}^{3}$ concentrated $\mathrm{HNO}_{3}$, boiled for $1.5 \mathrm{~h})$ and weighing of the dried solid residue $\left(105^{\circ} \mathrm{C}\right.$ for $24 \mathrm{~h})$.

\subsubsection{Statistics}

Each of the analyses was carried out in triplicate and the results were presented by the mean value and the standard deviation $(n=3)$.

\section{Results and discussion}

\subsection{Glyceride oil in unripe and under-ripe Cape gooseberry seeds; fatty acid and tocopherol composition of seed oil}

The moisture content of the analyzed Cape gooseberry seeds in the study was $8.70 \pm 0.08 \%$ (unripe) and $9.83 \pm 0.09 \%$ (under-ripe), respectively.

Unripe seeds contained $6.60 \pm 0.06 \%$ glyceride oil (DW), while the yield from under-ripe seeds was $21.75 \pm 0.20 \%$. As anticipated, the results proved significant differences in seed oil content in the two ripeness stages; the seeds of unripe, not fully developed fruit contained about 3-time less lipids, which had been observed as a common trend in other oil containing fruit seeds. For example, the yield of lipid fraction from seeds of unripe Ziziphus rugosa Lamk. fruit was $0.78 \pm 1.70 \%$, and that from ripe fruit seeds - $10.75 \pm 5.86 \%$ [43]. Respectively, red (unripe) fruit of Pistacia lentiscus L. yielded nearly 3 -time less oil $(11.25 \pm 2.27 \%)$ than black (ripe) fruit (32.18 $\pm 1.87 \%$ ) [44]. Similar increase in seed oil content with fruit maturation were reported for other fruits, as well - mango (unripe, $1.15 \pm 0.07 \%$ and ripe, $2.05 \pm 0.07 \%)$, papaya $(1.56 \pm 0.05 \%$ and $2.27 \pm 0.07 \%)$, pineapple $(0.47 \pm 0.07 \%$ and $1.23 \pm 0.11 \%)$, and orange $(1.49 \pm 0.07 \%$ and $1.66 \pm 0.07 \%)$ [45]. Furthermore, previous data from the investigation of the chemical composition of the seeds from fully ripe fruit of the same Cape gooseberry variety and production site, as in this study, showed $22.23 \%$ seed oil content [5], which supported the trend of oil yield increase with fruit ripeness stage.

The results from the analysis of the fatty acid (FA) composition of the lipid fraction of unripe and under-ripe Cape gooseberry seeds is presented in table 1 .

Table 1. Fatty acid (FA) composition of the seed oil from unripe and under-ripe Cape gooseberry fruit

\begin{tabular}{|l|l|c|c|}
\hline \multicolumn{2}{|l|}{ Fatty acids (\%) } & Unripe & Under-ripe \\
\hline $\mathrm{C}_{8: 0}$ & Caprylic & $\mathrm{nd}^{1}$ & nd \\
\hline $\mathrm{C}_{12: 0}$ & Lauric & $1.31 \pm 0.01$ & $0.09 \pm 0.0$ \\
\hline $\mathrm{C}_{14: 0}$ & Myristic & $1.72 \pm 0.01$ & $0.32 \pm 0.0$ \\
\hline $\mathrm{C}_{15: 0}$ & Pentadecanoic & $1.11 \pm 0.01$ & $0.21 \pm 0.0$ \\
\hline $\mathrm{C}_{16: 0}$ & Palmitic & $26.00 \pm 0.25$ & $17.58 \pm 0.16$ \\
\hline $\mathrm{C}_{16: 1}$ & Palmitoleic & $0.67 \pm 0.0$ & $1.21 \pm 0.01$ \\
\hline $\mathrm{C}_{17: 0}$ & Margaric & $0.72 \pm 0.0$ & nd \\
\hline $\mathrm{C}_{18: 0}$ & Stearic & $7.64 \pm 0.07$ & $1.08 \pm 0.01$ \\
\hline $\mathrm{C}_{18: 1}$ & Oleic & $28.71 \pm 0.27$ & $14.31 \pm 0.13$ \\
\hline $\mathrm{C}_{18: 2}$ & Linoleic & $27.56 \pm 0.26$ & $62.50 \pm 0.61$ \\
\hline & Linoleic & $0.92 \pm 0.0$ & $\mathrm{nd}$ \\
$\mathrm{C}_{18: 2}$ & (trans) & & \\
\hline $\mathrm{C}_{18: 3}$ & Linolenic & $0.30 \pm 0.0$ & $0.19 \pm 0.0$ \\
\hline $\mathrm{C}_{20: 0}$ & Arachidic & $0.67 \pm 0.0$ & $0.31 \pm 0.0$ \\
\hline $\mathrm{C}_{20: 1}$ & Gadoleic & $0.28 \pm 0.0$ & $0.42 \pm 0.0$ \\
\hline $\mathrm{C}_{20: 2}$ & Eicosadienoic & $1.62 \pm 0.01$ & $1.29 \pm 0.01$ \\
\hline $\mathrm{C}_{22: 0}$ & Behenic & $0.77 \pm 0.0$ & $0.49 \pm 0.0$ \\
\hline Saturated FAs & 39.94 & 20.08 \\
\hline Unsaturated FAs & 60.06 & 79.92 \\
\hline \multicolumn{2}{|c|}{ Monounsaturated FAs } & 29.66 & 15.94 \\
\hline \multicolumn{2}{|l|}{ Polyunsaturated FAs } & 30.40 & 63.98 \\
\hline
\end{tabular}

${ }^{1}$ not detected

The obtained results revealed quantitative differences in the FA content of the studied seed oils. Data showed that the lipid fraction of unripe seeds contained oleic (28.71\%), linoleic $(27.56 \%)$ and palmitic $(26.00 \%)$ acids as the main FAs, at a ratio of unsaturated to saturated FAs of about 1.5:1 and nearly equal polyunsaturated and monounsaturated FA ratio (about 1:1). The lipid fraction in under-ripe seeds, in turn, was dominated by linoleic $(62.50 \%)$, palmitic $(17.58 \%)$ and oleic $(14.31 \%)$ acids; the ratio between unsaturated and saturated FAs was about $4: 1$, the same as that between polyunsaturated and 
monounsaturated FAs (about 4:1).

Thus, it could be reasonably assumed that both unripe and under-ripe Cape gooseberry seeds have the potential to be regarded as sources of glyceride oil rich in linoleic $(27.56-62.50 \%)$ and oleic (14.31-28.71\%) acids, recognized as beneficial in the prevention of cardiovascular diseases, similar to grape, melon, tobacco, poppy, and other seeds [46]. Comparing the two stages in fruit development in the study, the most significant variations during plant vegetation were found with regard to palmitic, stearic and oleic acids (decrease of about 1.5, 7 and 2 times, respectively), and linoleic acid (increase of about 2 times).

Comparison of our results with previous data on Cape gooseberry seed oil composition (from ripe fruit) revealed some numerical differences in the FA profile. For instance, a previous study [11] also identified linoleic (76.1\%), oleic (11.7\%) and palmitic (7.3\%) acids as the main FAs in Cape gooseberry seed oil, at a ratio of unsaturated to saturated FAs of 87.2:12.8; similar proportions were reported in other studies [12, 14, 22]. Therefore, it could be summarized that there was a significant increase in the content of unsaturated FAs parallel to the advance in fruit maturity stage (mostly of linoleic acid) at the expense of a decrease in the content of saturated FAs (mostly palmitic, stearic and myristic acids) and some individual unsaturated FAs (oleic acid).

The individual tocopherol composition of the oil from unripe and under-ripe seeds is presented in table 2.

Table 2. Tocopherol composition of the seed oil from unripe and under-ripe Cape gooseberry fruit

\begin{tabular}{|c|c|c|}
\hline Tocopherols & Unripe & Under-ripe \\
\hline$\alpha$-Tocopherol (\%) & nd $^{1}$ & $2.11 \pm 0.02$ \\
\hline$\beta$-Tocopherol (\%) & $14.90 \pm 0.13$ & $44.01 \pm 0.43$ \\
\hline$\gamma$-Tocopherol (\%) & $3.02 \pm 0.02$ & $24.92 \pm 0.23$ \\
\hline$\gamma$-Tocotrienol (\%) & $56.78 \pm 0.55$ & $3.56 \pm 0.03$ \\
\hline$\delta$-Tocopherol (\%) & $25.30 \pm 0.24$ & $25.40 \pm 0.24$ \\
\hline Tocopherol content (mg/kg) & 8354 & 7118 \\
\hline \multicolumn{3}{|c}{ 1 not detected }
\end{tabular}

As seen from the data, the tocopherol fraction of the seed oil from unripe fruit was definitely dominated by $\gamma$ tocotrienol $(56.78 \%)$. At the same time, $\gamma$-tocotrienol content was significantly low in the oil extracted from under-ripe seeds (3.56\%, 16-time reduction). Significant differences in the tocopherol profile of the analyzed seed oils were observed with regard to $\beta$-tocopherol $(14.90 \%$ vs. $44.01 \%$; increase of about 3 times) and $\gamma$-tocopherol ( $3.02 \%$ vs. $24.92 \%$; increase of about 8 times), as well. $\delta$ Tocopherol content was not affected by fruit maturity stage, with identical levels in the two oils. Previous studies on $P$. peruviana seed oil (ripe fruit) had also identified $\beta-, \gamma$ - and $\delta$-tocopherols as the main oil tocopherols, and our results were fully consistent with that $[4,11,12,14]$. Considering previously published data about the tocopherol composition of the seed oil isolated from fully ripe Cape gooseberry fruit of the same variety and production site $(2833 \mathrm{mg} / \mathrm{kg}$ in ripe fruit, respectively) [5], the current results revealed clear trend of significant decrease in the total content of biologically active tocopherols during plant vegetation period.
Similarly, trend existence was supported by current results with regard to the reduction in $\gamma$-tocotrienol content (not identified in ripe fruit seed oil), the increase in $\beta$-tocopherol content $(54.7 \%$ in ripe fruit), and the preservation in $\delta$-tocopherol content $(25.8 \%$ in ripe fruit) [5].

\subsection{Minerals in the seeds of unripe and under- ripe Cape gooseberry fruit}

The results from the elemental analysis of mineral content in the seeds of unripe and under-ripe Cape gooseberry fruit are presented in table 3.

Table 3. Mineral composition of seeds from unripe and underripe Cape gooseberry fruit

\begin{tabular}{|c|c|c|}
\hline Mineral $(\mathrm{mg} / \mathrm{kg})$ & Unripe & Under-ripe \\
\hline $\mathrm{K}$ & $10391.43 \pm 47.03$ & $5596.58 \pm 14.26$ \\
\hline $\mathrm{Na}$ & $1752.10 \pm 6.21$ & $450.84 \pm 1.78$ \\
\hline $\mathrm{Ca}$ & $1109.04 \pm 3.24$ & $730.66 \pm 2.03$ \\
\hline $\mathrm{Mg}$ & $2162.16 \pm 7.77$ & $3513.41 \pm 14.66$ \\
\hline $\mathrm{Fe}$ & $121.16 \pm 0.36$ & $83.56 \pm 0.27$ \\
\hline $\mathrm{Mn}$ & $20.97 \pm 0.08$ & $23.32 \pm 0.08$ \\
\hline $\mathrm{Cu}$ & $13.98 \pm 0.04$ & $7.77 \pm 0.03$ \\
\hline $\mathrm{Zn}$ & $53.59 \pm 0.11$ & $46.64 \pm 0.10$ \\
\hline $\mathrm{Pb}$ & $6.99 \pm 0.02$ & $3.89 \pm 0.01$ \\
\hline $\mathrm{Cd}$ & $<0.01$ & $<0.01$ \\
\hline $\mathrm{Cr}$ & $2.33 \pm 0.01$ & $<0.01$ \\
\hline
\end{tabular}

As seen from the data in table 3, fruit development at those pre-ripeness stages was accompanied by changes in the mineral composition of the seeds. As a general observation, the content of the analyzed macro and micro minerals was approximately 1.5-2 times higher in the seeds from unripe fruit compared with the respective concentrations in under-ripe seeds. Exceptions in that trend were $\mathrm{Mg}$ and $\mathrm{Mn}$, with slightly elevated levels in under-ripe seeds. The observation that fruit maturation decreases the content of macro and micro minerals in Cape gooseberry seeds was further supported by the parallel to previously published data about the mineral composition of the seeds from fully ripe fruit of the same variety and origin [5], the latter being considerably lower than the current values.

The study identified $\mathrm{K}$ and $\mathrm{Mg}$ as the main macro minerals; and, respectively, $\mathrm{Zn}$ and $\mathrm{Fe}$ as the main micro minerals in Cape gooseberry seeds, regardless of ripeness stage. $\mathrm{K}, \mathrm{Na}, \mathrm{Ca}$, and $\mathrm{Mg}$ concentrations in the study were higher than some previously reported data [9, 47-49], inclusive that about fruit of the same origin [50], while micro mineral contents ( $\mathrm{Fe}, \mathrm{Mn}, \mathrm{Cu}, \mathrm{Zn}$ ) established no such uniform trend, being either higher or close to reported data. Those differences obviously reflected the influence of fruit ripeness discussed above (published data regarded only fully ripe fruit), but value comparison also supported the assumption that the seeds were the center of mineral accumulation in Cape gooseberry fruit, as all of the studies above considered either whole fruit or fruit pulp (fruit meal) alone. Further arguments in favor of that observation could be found in the reported mineral contents in the seed/peel waste powder from Cape gooseberry fruit [17], which were very close to our results 
for the isolated seeds both in this and in previous studies $[5,6]$.

It could be summarized that the high macro and micro mineral content in the seeds of unripe and under-ripe Cape gooseberry fruit substantiated our hypothesis about the nutrient value of fruit not suited for harvesting, marketing and processing (non-standard, currently discarded biomass), thus suggesting definite potential for use in the development of value-added products (e.g. functional foods and feed).

\subsection{Protein, amino acid and cellulose content in the seeds of unripe and under-ripe}

In order to expand the data about the nutrient composition of Cape gooseberry seeds and the use potential of unripe and under-ripe fruit, plant samples were analyzed in terms of protein, amino acid and cellulose content.

The results revealed no significant change in protein content between the two fruit ripeness stages in the study; unripe seeds contained $18.44 \pm 0.17 \%$ protein and underripe seeds $-17.83 \pm 0.16 \%$. Data approximated the protein content in other plant materials (sunflower, safflower, and rapeseed) [51-53], thus characterizing the seeds of both types of discarded fruit as good sources of plant protein.

The amino acid composition of protein in the analyzed seeds is presented in table 4 .

Table 4. Amino acid composition of seeds from unripe and under-ripe Cape gooseberry fruit

\begin{tabular}{|c|c|c|}
\hline Amino acid (mg/g) & Unripe & Under-ripe \\
\hline Aspartic acid & $1.23 \pm 0.01$ & $6.51 \pm 0.05$ \\
\hline Serine & $2.44 \pm 0.02$ & $2.65 \pm 0.02$ \\
\hline Glutamic acid & $19.24 \pm 0.18$ & $2.34 \pm 0.02$ \\
\hline Glycine & $5.75 \pm 0.05$ & $5.08 \pm 0.04$ \\
\hline Histidine & $2.01 \pm 0.01$ & $1.53 \pm 0.01$ \\
\hline Arginine & $28.28 \pm 0.27$ & $34.27 \pm 0.33$ \\
\hline Threonine & $12.12 \pm 0.11$ & $10.82 \pm 0.09$ \\
\hline Alanine & $22.75 \pm 0.21$ & $21.28 \pm 0.20$ \\
\hline Proline & $18.71 \pm 0.17$ & $11.56 \pm 0.10$ \\
\hline Cysteine & $3.80 \pm 0.03$ & $3.35 \pm 0.03$ \\
\hline Valine & $11.87 \pm 0.10$ & $11.82 \pm 0.10$ \\
\hline Methionine & $4.23 \pm 0.03$ & $1.88 \pm 0.01$ \\
\hline Lysine & $14.68 \pm 0.13$ & $14.07 \pm 0.13$ \\
\hline Isoleucine & $14.59 \pm 0.13$ & $15.48 \pm 0.14$ \\
\hline Leucine & $2.52 \pm 0.02$ & $2.61 \pm 0.02$ \\
\hline Phenylalanine & $1.60 \pm 0.01$ & $1.65 \pm 0.01$ \\
\hline Tyrosine & $0.59 \pm 0.0$ & $8.47 \pm 0.07$ \\
\hline
\end{tabular}

The results showed that the dominant amino acids in both seed samples were arginine and alanine. Significant differences were observed only in a limited number of amino acids. The content of aspartic acid increased considerably between the two ripeness stages (about 5 times, from 1.23 to $6.51 \mathrm{mg} / \mathrm{g}$ ), as did the content of tyrosine (about 14 times, from 0.59 to $8.47 \mathrm{mg} / \mathrm{g}$ ); the trend of aspartic acid and tyrosine increase with fruit ripening was supported by the data about the ripe fruit seeds of the same variety $(10.11 \mathrm{mg} / \mathrm{g}$ and $10.91 \mathrm{mg} / \mathrm{g}$, respectively) [5]. On the contrary, significant decrease was observed in the contents of glutamic acid (from 19.24 to $2.34 \mathrm{mg} / \mathrm{g}$, about 8 times) and methionine (from 4.23 to
$1.88 \mathrm{mg} / \mathrm{g}$, about 2 times). The contents of other amino acids were practically identical in the unripe and underripe seeds.

There were numerical variations to the data about the amino acid profile of the dehydrated seed/peel waste from juice extraction [17], which could be explained by the different ripeness stage and fruit fractions analyzed, the main amino acids in that study being glutamic acid, 18.09 $\mathrm{g} / 100 \mathrm{~g}$ protein; arginine, $11.57 \mathrm{~g} / 100 \mathrm{~g}$ protein; aspartic acid, $7.82 \mathrm{~g} / 100 \mathrm{~g}$ protein, and leucine, $5.87 \mathrm{~g} / 100 \mathrm{~g}$ protein.

It should be noted the high content of lysine in the seeds $(14.68 \mathrm{mg} / \mathrm{g}$ and $14.07 \mathrm{mg} / \mathrm{g}$, respectively), which is typically a limiting amino acid in animal nutrition; moreover, lysine contents in both unripe and under-ripe seeds significantly exceeded that registered in the seed fraction of fully ripe fruit $(3.07 \mathrm{mg} / \mathrm{g})$ [5]. As seen from the data, the share of other essential amino acids was also sufficiently high, suggesting good protein quality of the analyzed agricultural waste.

In turn, protein and cellulose proportion in the analyzed Cape gooseberry seeds was also favorable; the seeds contained cellulose in comparable amounts, $25.63 \pm 0.24 \%$ in unripe seeds and $26.14 \pm 0.25 \%$ in underripe seeds, thus approximating the cellulose content of sunflower meal, for example (27-31\%) [52].

\section{Conclusions}

The seeds of unripe and under-ripe Cape gooseberry fruit, currently a discarded by-product in plant cultivation, contained various macro and micronutrients - protein, essential amino acids, cellulose, glyceride oil, unsaturated fatty acids, tocopherols, and minerals, which substantiated their nutritional value. The results from this baseline study suggested that the seeds from both unripe and under-ripe fruit had definite potential in waste recovery and could also be considered for nutritive purposes (animal feed and food product development); of course, further research is needed to reveal in detail their functionality.

\section{References}

1. W.-N. Zhang, W.-Y. Tong, Chem. Biodivers. 13, 48-65 (2016)

2. L. Puente, C. Pinto-Muñoz, E. Castro, M. Cortés, Food Res. Int. 44, 1733-1740 (2011)

3. J. Muniz, A. Kretzschmar, L. Rufato, T. Pelizza, A. Rufato, T. Macedo, Ciênc. Rural. 44, 964-970 (2014)

4. M.-L. Olivares-Tenorio, M. Dekker, R. Verkerk, M. van Boekel, Trends Food Sci. Technol. 57, 83-92 (2016)

5. V. Popova, Z. Petkova, T. Ivanova, M. Stoyanova, N. Panayotov, N. Mazova, A. Stoyanova, Turk. J. Agric. For. 44, 642-650 (2020)

6. V. Popova, Z. Petkova, T. Ivanova, M. Stoyanova, N. Mazova, A. Stoyanova, Grasas Aceites. 72, e402 (2021)

7. C.A.G. Sbrussi, C. Zucareli, A.M. Prando, B.V. de A.B. da Silva, Rev. Ciênc. Agron. 45, 543-549 (2014)

8. S. Licodiedoff, L. Koslowski, R. Ribani, Acta Sci., Technol. 35, 393-399 (2013) 
9. E. Rodrigues, I. Rockenbach, C. Cataneo, L. Gonzaga, E. Chaves, R. Fett, Ciência Tecnol. Aliment. 29, 642-654 (2009)

10. E. Hegazy, A. Ali, H. El-Sayed, J. Kassem, Asian Food Sci. J. 7, 1-10 (2019)

11. M. Ramadan, J.-T. Mörsel, J. Agric. Food Chem. 51, 969974 (2003)

12. M.F. Ramadan, Food Res. Int. 44, 1830-1836 (2011)

13. N. Singh, S. Singh, P. Maurya, M. Arya, F. Khan, D.H. Dwivedi, S.A. Saraf, Indian J. Nat. Prod. Resour. 10, 97-110 (2019)

14. D. Nocetti, H. Núñez, L. Puente, A. Espinosa, F. Romero, J. Sci. Food Agric. 100, 4335-4346 (2020)

15. Ö. Ertürk, M. Çol Ayvaz, Z. Can, Ü. Karaman, K. Korkmaz, Indian J. Pharm. Edu. Res. 51, 213-216 (2017)

16. M.F. Ramadan, J.-T. Mörsel, Goldenberry (Physalis peruviana) oil (Springer Nature, Switzerland, 2019)

17. S. Mokhtar, H. Swailam, H. Embaby, Food Chem. 248, 1-7 (2018)

18. E.I. Adeyeye, M.O. Aremu, FUW Trends Sci. Technol. 2, 334-341 (2017)

19. D. Morais, E. Rotta, S. Sargi, E. Bonafe, R. Suzuki, N. Souza, M. Matsushita, J. Visentainer, J. Braz. Chem. Soc. 28, 308-318 (2017)

20. N. Panayotov, Agric. Sci. 1, 9-12 (2009)

21. N. Panayotov, Agric. Food 4, 115-121 (2016)

22. M. Hristozkova, M. Geneva, I. Stancheva, I. Iliev, C. AzcónAguilar, J. Plant Protect. Res. 57, 173-184 (2017)

23. N. Panayotov, A. Popova, Sci. Papers, Hortic. 49, 245- 250 (2015)

24. D.B. Singh, A.A. Pal, N. Ahmed, A. Mirza, Asian J. Hortic. 7, 374-378 (2012)

25. C.S.M. Lima, R. Manica-Berto, G.A. Silva, L. Rufato, A.R. Rufato, Rev. Bras. Frutic. 31, 1060-1068 (2009)

26. A.J.G. Collazos, E.A.V. Munar, F.A.V. Ayala, K.D.G. Velandia, Rev. Mex. Cienc. Agríc. 10, 1273-1285 (2019)

27. H.E. Balaguera-López, C.A. Martínez-Cárdenas, A. Herrera-Arévalo, Bioagro. 28, 117-124 (2016)

28. C.E. Narváez-Cuenca, Á. Mateus-Gómez, L.P. RestrepoSánchez, Agron. Colomb. 32, 232-237 (2014)

29. L. Etzbach, A. Pfeiffer, F. Weber, A. Schieber, Food Chem. 245, 508-517 (2018)

30. Codex Alimentarius. Standard for Cape Gooseberry (Standard CXS 226-2001) (FAO/WHO, Roma, 2011)

31. NTC. Norma Técnica Colombiana 4580 (ICONTEC, Bogotá, 1999)

32. N. Panayotov, A. Popova, Acta Hortic. Regiotec. 19, 18-24 (2016)

33. N. Panayotov, A. Popova, Turk. J. Agric. Nat. Sci. 1, 11341140 (2014)

34. M. Nikolova, T. Prokopov, T. Ivanova, V. Popova, D. Taneva, M. Dimov, N. Mazova, J. Chem. Technol. Metall. 55, 2076-2084 (2020)

35. V. Popova, T. Ivanova, M. Stoyanova, N. Mazova, N. Panayotov, A. Stoyanova, IOP Conf. Ser., Mat. Sci. Eng. 1031, 012094 (2021)

36. ISO 659:2014. Oilseeds. Determination of oil content (Reference method) (ISO, Geneva, 2014)

37. ISO 12966-1:2014. Animal and vegetable fats and oils. Gas chromatography of fatty acid methyl esters - Part 1 :
Guidelines on modern gas chromatography of fatty acid methyl esters (ISO, Geneva, 2014)

38. ISO 12966-2:2017. Animal and vegetable fats and oils. Gas chromatography of fatty acid methyl esters - Part 2: Preparation of methyl esters of fatty acids (ISO, Geneva, 2017)

39. ISO 9936:2016. Animal and vegetable fats and oils. Determination of tocopherol and tocotrienol contents by high-performance liquid chromatography (ISO, Geneva, 2016)

40. ISO 14084:2003. Foodstuffs. Determination of trace elements. Determination of lead, cadmium, zinc, copper and iron by atomic absorption spectrometry (AAS) after microwave digestion (ISO, Geneva, 2003)

41. AOAC. Method 976.06 (AOAC Int., Gaithersburg, 2016)

42. O. Brendel, P. Iannetta, D. Stewart, Phytochem. Anal. 11, $7-$ $10(2000)$

43. S.R. Krishnamurthy, P. Sarala, Indian J. Nat. Prod. Resour. 3, 20-27 (2012)

44. K. Boudieb, S. Ait Slimane-Ait Kaki, H. Amellal-Chibane, Not. Bot. Horti Agrobot. Cluj-Napoca. 47, 836-847 (2019)

45. P. Adie, P. Ediga, R. Wuana, Asian J. Appl. Chem. Res. 4, 1-9 (2019)

46. A. Popov, P. Ilinov, Chemistry of lipids (Nauka i Izkustvo, Sofia, 1986)

47. P. Leterme, A. Buldgen, F. Estrada, A. Londoño, Food Chem. 95, 644-652 (2006)

48. A. Öztürk, Y. Özdemir, B. Albayrak, M. Simşek, K. Yildirim, Sci. Papers, Hortic. 61, 293-297 (2017)

49. A. Eken, B. Ünlü-Endirlik, A. Baldemir, S. Ilgün, B. Soykurt, O. Erdem, C. Akay, J. Clin. Anal. Med. 7, 291-294 (2016)

50. N. Petkova, V. Popova, T. Ivanova, N. Mazova, N. Panayotov, A. Stoyanova, Food Res. 5, 191-202 (2021)

51. V. Heuzé, G. Tran, P. Chapoutot, D. Renaudeau, D. Bastianelli, F. Lebas, Safflower (Carthamus tinctorius) seeds and oil meal (Feedipedia, INRA, CIRAD, AFZ and FAO, 2015)

52. V. Heuzé, G. Tran, P. Hassoun, M. Lessire, F. Lebas, Sunflower meal (Feedipedia, INRA, CIRAD, AFZ and FAO, 2016)

53. V. Heuzé, G. Tran, D. Sauvant, M. Lessire, F. Lebas, Rapeseeds (Feedipedia, INRA, CIRAD, AFZ and FAO, 2019) 